Brit. F. industr. Med., 1968, 25, 196.

\title{
Nephropathy in Chronic Lead Poisoning
}

\author{
RUTH LILIS, N. GAVRILESCU, B. NESTORESCU, C. DUMITRIU, \\ and ANA ROVENTA
}

\author{
From the Clinic of Occupational Diseases, Institutul de Igienă, Bucharest, Roumania
}

This paper presents a study of renal function in 102 patients with lead poisoning admitted to the Occupational Diseases Clinic in Bucharest during the past ro years; nearly half the patients had no history of lead colic. Every possible cause of renal damage, other than lead, was excluded by a careful differential diagnosis.

Renal function was investigated by repeated determinations of blood urea, creatinine and uric acid, urea clearance, and endogenous creatinine clearance tests.

Significant decreases of the clearance values (less than $50 \mathrm{ml} . / \mathrm{min}$. urea clearance and less than $80 \mathrm{ml} . / \mathrm{min}$. creatinine clearance), persistent high blood urea (more than $50 \mathrm{mg} . / 100 \mathrm{ml}$.), and high blood creatinine (more than $1 \cdot 2 \mathrm{mg} . / 100 \mathrm{ml}$.) were found in a significant number of cases. These signs of impaired renal function were more frequent in the group of patients with chronic lead poisoning who had had several episodes of colic and an occupational exposure of more than Io years. A high blood pressure was also found more frequently in this group of patients.

Undercompensated and decompensated renal failure was found in 17 patients, most of whom had been exposed to lead for more than ro years and had a history of several attacks of colic. Arterial hypertension accompanied the chronic renal failure in 13 patients, the renal impairment generally preceding the rise in blood pressure by several years.

The duration of occupational lead exposure, the high absorption in the past, and the long period of observation of these patients, most of whom were repeatedly hospitalized, may explain the relatively high incidence ( 7 cases) of nephropathy with chronic renal failure in the present group.

Impairment of urea clearance seems to be the earliest sign, at a time when the creatinine clearance is still normal. As the duration of exposure lengthens and the patient is subjected to active episodes of poisoning the creatinine clearance also deteriorates. Persistent urea retention and high creatininaemia may follow in time, accompanied rather frequently by arterial hypertension. A study of some of the cases followed for several years demonstrated this progressive evolution of lead nephropathy.

A functional and transitory impairment of renal function is very probably caused by an impairment of intrarenal circulation, resulting from marked vasoconstriction of the renal vessels, forming part of the generalized vasoconstriction of lead poisoning. Prolonged exposure and frequently recurring episodes of acute poisoning may lead to progressive impairment of renal function and to the development of organic lesions.

Special attention should be paid to renal function tests in all cases with prolonged exposure to lead in order to prevent the development of severe lead nephropathy.

The question whether lead poisoning can cause a chronic nephropathy is of interest at the present time not only in occupational medicine but also in paediatrics, general medicine, and nephrology. If such an effect is established, it clearly becomes very important in the long-term prognosis of chronic lead poisoning. Modern advances in the investigation of renal function make it possible to detect

Received for publication August 10, 1967. certain pathological states earlier than has been possible hitherto.

In the past, many authors have held that chronic lead poisoning might cause chronic renal damage with progressive Bright's disease (Oliver, I9I4; Legge and Goadby, 1912; Fishberg, 1939; Nye, 1933; Lane, 1949). On the other hand, some American workers have denied that lead produces any permanent renal damage (Belknap, 1935; Dreessen, Edwards, Reinhart, Page, Webster, 
Armstrong, and Sayers, 194I). It seems certain that these divergent views result from the fact that improved environmental conditions have substantially reduced exposure to lead, reducing absorption and the risk of poisoning. (This means that the investigation of any permanent renal effect of lead must be made over a long period.) At the same time, because of closer medical supervision of lead workers, considerably fewer workers develop severe lead poisoning because suspension from lead work or an improvement in working conditions are likely to follow the detection of early signs of lead poisoning.

Some interesting questions have been raised by observations on chronic nephropathy in certain parts of Australia, where lead poisoning in children has previously been quite frequent. Clinical, epidemiological, statistical and pathological studies, together with the demonstration of a high lead content in bones and a raised excretion following administration of sodium calcium edetate, strongly suggested a causal relationship between lead poisoning in childhood and chronic Bright's disease, becoming manifest perhaps only after decades (Henderson, 1955; Henderson and Inglis, 1957). Furthermore, it was suggested that, in children at least, chronic renal disease may develop as the result of excessive lead absorption, not in itself causing clinical lead poisoning.

Many years ago, when significant impairment of renal function was frequently observed after heavy and prolonged lead exposure, the methods of investigation of renal function were limited and reports were confined to clinical and pathological descriptions of the disease which were sometimes contradictory. Thus, Charcot and Gombault (I88I), Volhard and Suter (I918), Aub, Minot, Fairhall, and Reznikoff (1925), and Vigdorcik (1935) stated that lead poisoning might lead to a nephrosclerotic kidney with severe progressive renal insufficiency. The pathology of the disease was described as epithelial-parenchymatous damage, together with an interstitial process. Many authors (Legge and Goadby, 1912; Volhard and Suter, 1918; Brogsitter, 1922; Lane, 1949; Hamilton and Hardy, 1949; Crepet and Gobbato, 1957) recognized the importance of vascular lesions, with intimal proliferation and hyaline degeneration of the media. It was believed that an important role in this process was played by renal arterial vasoconstriction, part of the generalized vasoconstriction of lead colic, particularly when there had been recurrent episodes of lead colic.

Recently, more detailed tests of renal function have been used in cases of lead colic and have shown a reduction of renal blood flow and glomerular filtration rate together with an increase in total renal vascular resistance, mostly by an increased resistance in the afferent arterioles (Baldi and Sbertoli, 1957; Rădulescu, Dinischiotu, Maugsch, Ionescu, and Teodorescu Exarcu, 1957). Nevertheless many workers (Radoševic, Sarić, Beritić, and Knežević, I96I; Crutcher, 1963) consider that such changes are reversible and that a return to normal function may occur in to to I4 days.

Nowadays the possibility of chronic renal disease following prolonged lead work is considered to be remote. Thus, Lane (1949) found no evidence of renal damage among men working in a modern accumulator factory, although cases had occurred under old and bad conditions; Baader (1958) found only 12 patients with chronic nephropathy among 4,000 lead-exposed workers. Lane (1949) and Vigliani (1950) considered that such cases occurred only after heavy exposure to lead, usually of many years' duration and often with several episodes of colic. On the other hand, Rădulescu and his colleagues (1957) found a decrease in the urea and endogenous creatinine clearance levels in nearly one fifth of the cases of chronic lead poisoning which they investigated, even in patients with no history of lead colic.

Although, as with other heavy metals, massive acute poisoning causes damage to the convoluted tubules, clinically obvious tubular dysfunction is seldom seen in chronic lead poisoning. A small number of cases with proximal tubular dysfunction, exhibiting amino-aciduria, glycosuria, and hyperphosphaturia, have been described, mostly in children. Recently Blackman (1956), Landing and Hakai (1959), and Angevine, Kappas, de Gowin, and Spargo (I962) have described changes in the proximal tubular cells, seen on electron microscopy, which are quite different from those found in chronic nephropathies due to other causes, and these authors consider that the changes are specific for lead. The main features are typical intranuclear inclusions appearing as a network of osmophilic filaments together with alterations of the mitochondria. Similar changes have been found in rats after administration of lead for two months.

The present study is of renal function in patients with lead poisoning admitted to the Occupational Diseases Clinic during the past ro years.

\section{Patients and Methods}

The diagnostic criteria for lead poisoning used in the Occupational Diseases Clinic in Bucharest are those generally accepted. All our patients had been working for several years in plants where the risk of exposure to 
lead or lead oxides is well known-storage battery plants, lead and lead-alloy foundries, terracotta enamelling shops, etc. A significant number of lead poisoning cases had been traced to these working places in the past, pointing to a relatively high degree of exposure.

A high lead absorption in these patients was evidenced by repeated determinations of blood and urinary lead using the spectrophotometric dithizone method of Bessman and Layne (1955). As generally accepted, values of urinary lead greater than Ioo $\mu \mathrm{g}$./litre and of lead in whole blood greater than $40 \mu \mathrm{g} . / 100 \mathrm{ml}$. were taken to indicate increased absorption. Our experience has been that in workers with moderate exposure to lead, in the absence of any clinical symptoms, values of I $4 \pm 43 \mu \mathrm{g}$. $/$ litre in urine and $50 \pm 18 \mu \mathrm{g}$. $/ 100 \mathrm{ml}$. in blood may be found (Pilat, Preda, and Muica, 1964). However, such findings do not justify a diagnosis of lead poisoning, as no detectable ill-effects are found. Such cases are considered to have 'increased lead absorption'.

We consider that the presence of the following clinical picture is necessary for a diagnosis of 'chronic lead poisoning' to be made. The most frequent clinical symptoms are grouped in three main syndromes, asthenic, dyspeptic, and pseudorheumatic, sometimes occurring alone but more often associated in differing proportions. The most severe forms of lead poisoning are nowadays represented by lead colic. Radial paralysis and lead encephalopathy are now extremely rare in occupational lead poisoning. The blood and urinary levels of lead are generally well above the range of 'increased absorption', but there is no strict correlation between the severity of poisoning and these analytical findings. Indeed, the appearance of the clinical manifestations appears to be more directly related to a critical concentration of lead in certain lead-sensitive tissues, such as haematopoietic bone-marrow, brain, etc. Thus an important role may be played by the pool of 'easily accessible' lead present in the body at a given time.

As a test for the estimation of this 'easily accessible' lead, we determined the total amount of lead excreted after the administration of sodium calciumedetate. Ten millilitres of a $10 \%$ solution of sodium calciumedetate were injected every 12 hours for 5 days. The amount of lead excreted in the first 24 hours and in the whole 5 days was determined. Previous work (Preda, Lilis, Nestorescu, and Roventa, 1963) had shown a significant difference in lead excretion, induced by sodium calciumedetate, between 'increased lead absorption' ( 5 days' excretion: mean $6 \mathrm{mg}$; range $2 \cdot 2-10 \mathrm{mg}$.) and 'chronic lead poisoning' ( 5 days' excretion: mean $14.8 \mathrm{mg}$.; range 6-23 mg.). In cases of lead colic the mean was $24.5 \mathrm{mg}$. lead in 5 days (range 7-40 mg.). We consider, therefore, that an excretion exceeding ro mg. of lead in a 5 days' test characterizes chronic lead poisoning.

Stippled red cell counts and the determination of urinary coproporphyrin by the spectrophotometric method of With (1955) were also used routinely. Stippled red cell counts were made by light ground examination after methanol fixation and staining with methylene blue-borate. These investigations are considered to indicate the toxic effects of lead on the haematopoietic bone marrow. A diagnosis of chronic lead poisoning required the finding of more than $\mathrm{I}, 000$ stippled red cells per million and an excretion of more than $400 \mu \mathrm{g}$. coproporphyrin per litre of urine (normal value less than $100 \mu \mathrm{g}$./litre).

Using these diagnostic criteria, we selected ro2 cases of confirmed lead-poisoning from the patients admitted during a period of Io years to the Occupational Diseases Clinic in Bucharest. In the cases selected, renal function had been investigated. Cases with 'increased lead absorption' were not considered in this study. We included only those cases in which every possible cause of renal damage, other than lead, could be excluded.

The differential diagnosis from 'endemic nephropathy', of the type described for certain circumscribed adjacent geographical areas of Yugoslavia, Bulgaria, and Roumania, was made by careful consideration of the epidemiological and clinical features. None of our patients came from or lived at any time in the wellcircumscribed zone of south-west Roumania where endemic nephropathy occurs. All came from cities, most of them from Bucharest, and endemic nephropathy has been reported only from rural areas. The clinical features of endemic nephropathy (low urinary density ( $\mathrm{I} \cdot 000-\mathrm{I} \cdot 0 \mathrm{IO})$, marked reduction of the concentrating power of the kidneys, marked urea retention, severe anaemia, and absence of hypertension), are quite different from the clinical picture in our cases.

From the IO2 cases so selected, 49 had chronic lead poisoning (without a history of lead colic), 20 had had one or more episodes of lead colic in the past, and 33 had been admitted with acute colic.

\section{Results}

The results of laboratory tests used in diagnosis are summarized in Table I.

The renal function tests carried out on all patients included repeated blood urea determinations by the Van Slyke manometric method, creatinine determinations by the photometric picrate method of Peters (1956), and urea clearance and endogenous creatinine clearance tests. Urine concentration (Volhard procedure) and blood uric acid determinations by the Heilmeyer-Krebs (I930) photometric method were carried out on only some of the patients. In our clinic the upper limits of normal values are as follows: blood urea, $50 \mathrm{mg}$./100 ml.; blood creatinine, I. $2 \mathrm{mg}$./100 ml.; blood (serum) uric acid, $7 \mathrm{mg}$. $/ 100 \mathrm{ml}$.

Basal blood pressures were measured repeatedly, as soon as the patients woke and before they got out of bed, by the indirect method using auscultation. Sphygmomanometer cuffs, 13 by $35 \mathrm{~cm}$., were used. The diastolic pressure was read when the auscultated sounds ceased; a measurement above 95 $\mathrm{mm}$. Hg was considered as diastolic hypertension. A systolic blood pressure of $150 \mathrm{~mm}$. $\mathrm{Hg}$ or above was regarded as representing systolic hypertension in persons under the age of 50 years. Above that age 
TABLE I

Results of Laboratory Tests Used in the Diagnosis of Lead Poisoning in io2 Patients Studied for ReNAL Function

\begin{tabular}{|c|c|c|c|c|c|c|c|c|}
\hline \multicolumn{5}{|l|}{ Tests } & \multicolumn{2}{|c|}{$\begin{array}{c}\text { Chronic Lead Poisoning } \\
\text { (69 cases) }\end{array}$} & \multicolumn{2}{|c|}{$\begin{array}{l}\text { Acute Lead Colic } \\
\text { (33 cases) }\end{array}$} \\
\hline $\begin{array}{l}\text { Urinary lead ( } \mu \mathrm{g} . / \text { litre) } \\
\text { Blood lead ( } \mu \mathrm{g} . / \mathrm{IO0} \mathrm{ml} \text {. whole blood) } \\
\text { Lead (mg.) excreted during } 5 \text { days of } \\
\text { istration . . } \ldots \\
\text { Urinary coproporphyrin }(\mu \mathrm{g} . / \text { litre) } \\
\text { Stippled red cells per million red cells }\end{array}$ & $\begin{array}{l}\cdots \\
\cdots \\
\text { sodium } \\
\ldots \\
\cdots \\
\cdots\end{array}$ & $\begin{array}{l}\cdots \\
\cdots \\
\text { calciumec } \\
\cdots \\
\cdots \\
\cdots\end{array}$ & $\begin{array}{l}\cdots \\
\cdots \\
\cdots \\
\cdots\end{array}$ & $\begin{array}{l}\cdots \\
\cdots \\
\cdots \\
\cdots \\
\cdots\end{array}$ & $\begin{array}{l}295 \\
74 \\
14 \cdot 92 \\
\text { I0I } 4 \\
2216\end{array}$ & $\begin{array}{c}135-592 \\
42-117 \\
8-27 \\
403-2078 \\
1100-7200\end{array}$ & $\begin{array}{r}379 \\
88 \\
27 \cdot 8 \\
2512 \\
6327\end{array}$ & $\begin{array}{c}195-595 \\
54-141 \\
13 \cdot 2-74 \cdot 2 \\
1051-7600 \\
1200-24000\end{array}$ \\
\hline
\end{tabular}

a systolic pressure of $160 \mathrm{~mm} . \mathrm{Hg}$ was regarded as the upper limit of normal values.

The patients with acute lead colic had their renal function investigated about two to four weeks after admission, that is, at least 8 to Io days after the disappearance of the colic and after the blood pressure and pulse rate had become normal because the well recognized urea retention and temporary lowering of the clearance tests during lead colic (explained by the renal vasoconstriction as part of the generalized vasoconstriction) did not form part of the study.
The duration of occupational exposure to lead was more than ro years for 45 patients and more than 20 years for I9 patients; the longest period of exposure in one case was 4I years. Two thirds of the patients were under 50 years of age and the majority were men (there were only three women). Almost half the cases had been admitted to the clinic on more than one occasion and had therefore been investigated more than once.

In Table II are presented the details of the findings of these investigations in different groups of patients classified as follows:

TABLE II

Results of Renal function Tests in io2 Cases of Lead Poisoning

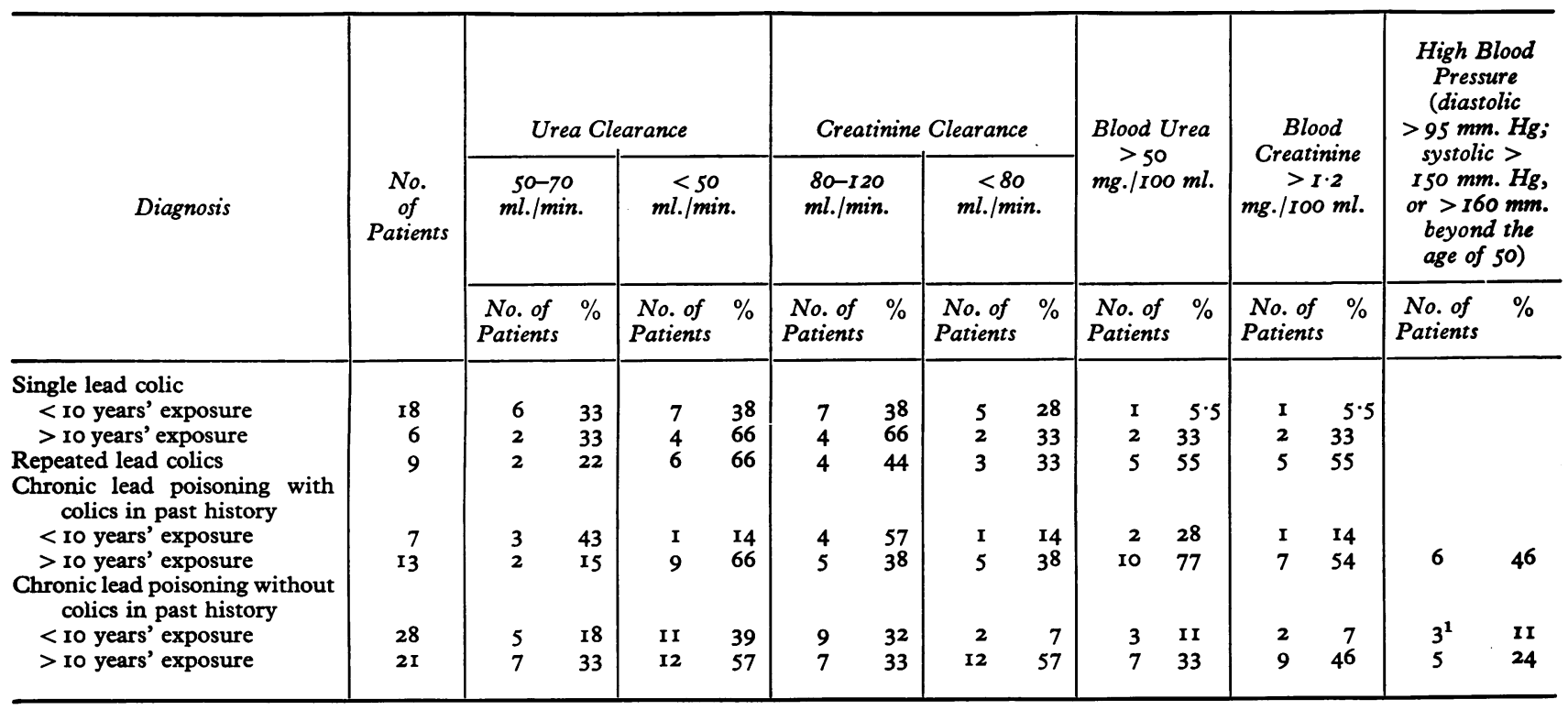

${ }^{1}$ One case where the readings of systolic pressure varied around $160 \mathrm{~mm} . \mathrm{Hg}$. 
Patients investigated after the first attack of lead colic

Less than Io years' exposure to lead More than ro years' exposure to lead Patients investigated after an attack of lead colic but with a history of previous attacks

Chronic lead poisoning with a history of several attacks of lead colic

Less than Io years' exposure to lead

More than Io years' exposure to lead Chronic lead poisoning with no history of lead colic

Less than ro years' exposure to lead

More than Io years' exposure to lead

Significant decreases of the clearance values, a persistent high blood urea, and a high blood creatinine were found more frequently in the group of patients with 'chronic lead poisoning', who had had several episodes of colic and an occupational exposure to lead of more than Io years.

A high blood pressure was found in $16 \%$ of the patients with chronic lead poisoning (without a history of colic) and in $33 \%$ of those with a history of lead colic. Considering only the groups with a longer exposure (more than Io years), a high blood pressure affected $24 \%$ of those without a history of lead colic and $46 \%$ of those with a history of colic.
Urinalysis yielded no pathological findings in the majority of cases. Only two patients had slight proteinuria $(0.25$ and $0.5 \mathrm{~g}$./litre) together with markedly altered clearance tests. Pathological sediment was also uncommon, being found only in cases of decompensated renal failure. During lead colic a transitory microscopic haematuria was sometimes observed.

The urine concentration test (Volhard) was done in 28 patients in whom other tests had indicated a renal disorder. It gave maximum concentration values of between $\mathrm{I} \cdot 020$ and $\mathrm{I} \cdot 026$, except in two patients with decompensated renal failure, in whom the maximum densities were $\mathrm{I} \cdot 0 \mathrm{I} 6$ and $\mathrm{I} \cdot 015$.

The blood uric acid, determined in 26 cases, had higher values in four cases of decompensated renal failure, and in only one case was the level over $8 \mathrm{mg}$. $/ 100 \mathrm{ml}$. These results, as well as the absence of symptoms of gout in all our patients, differ from the findings of other authors (Emmerson, 1963; Richet, Albahary, Ardaillou, Sultan, and MorelMaroger, 1964), who found such disorders in half of their cases of lead poisoning.

Undercompensated or decompensated renal failure was found in 17 patients, most of whom had been exposed to lead for more than ro years, and eight of them for more than 20 years (Table III). The majority of this group had a history of several

TABLE III

Lead PoIsoning With Undercompensated oR Decompensated Renal InSUfficiency

\begin{tabular}{|c|c|c|c|c|c|c|}
\hline Name & Age & Occupation & $\begin{array}{c}\text { Duration } \\
\text { of } \\
\text { Exposure } \\
\text { (yrs) }\end{array}$ & Clinical Form of Lead Poisoning & $\begin{array}{c}\text { Blood } \\
\text { Pressure } \\
\text { (mm. Hg) }\end{array}$ & Remarks \\
\hline $\begin{array}{l}\text { A.I. } \\
\text { W.R. }\end{array}$ & $\begin{array}{l}49 \\
57\end{array}$ & $\begin{array}{l}\text { Lead welding } \\
\text { Lead welding }\end{array}$ & 26 & $\begin{array}{l}\text { Repeated episodes of chronic saturnism } \\
\text { Repeated lead colics }\end{array}$ & $170 / 90$ & Atherosclerosis \\
\hline O.D. & 32 & Lead welding & 7 & Repeated episodes of chronic saturnism & $\begin{array}{l}180 / 120 \\
155 / 90\end{array}$ & Atherosclerosis \\
\hline P.P. & 53 & Lead welding & 27 & Repeated lead colics & $220 / 110$ & Atherosclerosis \\
\hline C.I. & 49 & Accumulator plant & 9 & Repeated colics & $190 /$ I 10 & \\
\hline C.A. & 36 & Battery plate welding & 14 & $\begin{array}{l}\text { Repeated episodes of chronic saturnism and } \\
\text { colics }\end{array}$ & & \\
\hline G.P. & 49 & Battery plate welding & 30 & Repeated lead colics & $160 / 90$ & \\
\hline G.I. & 45 & Battery plate welding & Io & Repeated lead colics & & \\
\hline O.F. & 61 & $\begin{array}{l}\text { Accumulator plant } \\
\text { (mechanic) }\end{array}$ & 23 & Repeated episodes of chronic saturnism & $240 / 115$ & \\
\hline E.I. & 52 & Lead plate foundry & 7 & Repeated lead colics & & \\
\hline H.M. & $4 \mathrm{I}$ & Lead foundry & 18 & Repeated episodes of chronic saturnism & $200 / 100$ & \\
\hline P.S. & 37 & Lead foundry & 7 & $\begin{array}{l}\text { Repeated episodes of chronic saturnism and } \\
\text { colics }\end{array}$ & $150 / 90$ & Radial paresis \\
\hline C.A. & 60 & Lead casting & 39 & $\begin{array}{l}\text { Repeated episodes of chronic saturnism and } \\
\text { colics }\end{array}$ & $200 / 110$ & Death \\
\hline $\begin{array}{l}\text { O.N. } \\
\text { S.I. }\end{array}$ & $\begin{array}{l}50 \\
59\end{array}$ & $\begin{array}{l}\text { Terracotta enamelling } \\
\text { Terracotta enamelling }\end{array}$ & $\begin{array}{l}37 \\
4 I\end{array}$ & $\begin{array}{l}\text { Repeated episodes of chronic saturnism } \\
\text { Repeated lead colics }\end{array}$ & $\begin{array}{l}190 / 110 \\
200 / 100\end{array}$ & Radial paresis \\
\hline M.I. & 56 & Terracotta enamelling & 39 & Repeated lead colics & $160 / 90$ & \\
\hline C.C. & 4I & Minium painting & I I & Repeated episodes of chronic saturnism & & \\
\hline
\end{tabular}


attacks of colic (up to six attacks) and two of them had radial paresis, a syndrome, rarely found nowadays in lead-exposed patients, which indicates severe poisoning. The ages of these patients with undercompensated or decompensated renal failure were less than 40 years in four cases, between $4 \mathrm{I}$ and 50 years in seven cases, and over 50 in the remaining six cases. Arterial hypertension accompanied chronic renal failure in 13 cases, the renal impairment generally preceding the rise in blood pressure by several years. A definite retinal angiopathy (grade I or II) was found in most of these patients.

One of the patients with decompensated renal failure and hypertension, who had worked for 39 years in conditions of particularly high lead exposure and had had repeated episodes of acute poisoning with several attacks of lead colic, died in azotaemic coma five years after the diagnosis of renal failure had been made on his first admission to our clinic, although exposure to lead was stopped completely from that time.

\section{Discussion}

These results suggest the importance of the duration of exposure and of repeated episodes of colic in the progressive development of renal failure, which at first is compensated but may become decompensated. The impairment of urea clearance appears rather early, at a time when the creatinine clearance is still normal or only slightly diminished, in cases with a shorter exposure. As the duration of exposure lengthens and the patient is subjected to several active episodes of poisoning the creatinine clearance also deteriorates. In time, persistent urea retention as well as high creatininaemia may supervene. At this stage hypertension may be found in a number of cases.

The repeated hospitalization of some of our patients enabled us to follow the time course of the development of renal damage. Thus, in a patient studied for nine years, who had six episodes of lead colic during this time, the urea clearance was seen to drop progressively from 75 to $36 \mathrm{ml}$./min., the creatinine clearance from 135 to $82 \mathrm{ml}$. $/ \mathrm{min}$., while the blood creatinine level increased from $I \cdot 2$ to I.7 mg./100 ml. Another patient, who had four episodes of colic in six years, showed an increase in blood urea from 47 to $6 \mathrm{I} \mathrm{mg}$. $/ 100 \mathrm{ml}$. (in colic-free intervals) and a steady fall of the urea clearance to $27 \mathrm{ml} . / \mathrm{min}$., and of the creatinine clearance to $68 \mathrm{ml}$./min. The undercompensated or decompensated renal insufficiency found in 17 cases-in patients with long and heavy exposures to lead giving rise to repeated episodes of acute poisoning -emphasizes the fact that the appearance of a lead nephropathy is still possible, especially in workers with longer occupational exposures (more than Io years).

The very long exposures of many of the patients, their high lead absorption in certain periods of their past history as well as the observation of these cases for a long time during several periods of hospitalization may explain the relatively high incidence of nephropathy with chronic renal failure in the group studied. Such an incidence cannot be found in a single examination of a group of leadexposed workers or in a single investigation of a group of patients with lead poisoning. The investigation demonstrates the value of prolonged medical supervision.

A functional and transitory impairment of renal function, frequently found during lead colic and sometimes, but less frequently, in the course of chronic lead poisoning, is very probably caused by an impairment of intrarenal circulation resulting from marked vasoconstriction of renal vessels, forming part of the generalized vasoconstriction of lead poisoning. The frequent repetition of such episodes may lead-as we observed in a number of patients followed for several years-to a progressive impairment of renal function. The return to normal was slower after each fresh episode and finally was no longer attained. If the fall in the urea and creatinine clearance values continues, or if it appears independently of an exacerbation of toxic symptoms, the development of organic lesions is probable.

The importance of renal damage in the long-term prognosis of patients with chronic lead poisoning justifies careful examination of renal function in all cases with long exposure to lead, in order to prevent the development of severe lead nephropathy by timely interruption of occupational exposure.

\section{REFERENCES}

Angevine, J. M., Kappas, A., De Gowin, R. L., and Spargo, B. H. (1962). Renal tubular nuclear inclusions of lead poisoning. A clinical and experimental study. Arch. Path., 73, 486-494.

Aub, J. C., Minot, A. S., Fairhall, L. T., and Reznikoff, P. (1925). Lead poisoning. Medicine (Baltimore), 4, I-250.

Baader, E. W. (1958). Maroc Médical, 37, 409-415.

Baldi, G., and Sbertoli, C. (1957). La nefropatia saturnina. Med. d. Lavoro, 48, 533-538.

Belknap, E. L. (1935). Control of lead poisoning in the worker. F. Amer. med. Ass., 104, 205-210.

Bessman, S. P., and Layne, E. C. (1955). Rapid procedure for determination of lead in blood or urine in the presence of organic chelating agents. F. Lab. clin. Med., 45, 159-166

Blackman, S. S. (1956). Intranuclear inclusion bodies in the kidney caused by lead poisoning. Bull. Fohns Hopk. Hosp., 58, 384-403. 
Brogsitter, M. (1922). Nierenveränderungen bei Bleivergiftung und Gicht. Dtsch. Arch. klin. Med., 139, I29-I42.

Charcot, J. M., and Gombault, P. H. (188I). Note relative à l'étude anatomique de la néphrite saturnine expérimentale. Arch. Physiol. norm. path., 8, 126, 154.

Crepet, M., and Gobbato, F. (1957). Alterazioni dell'apparato cardio-vascolare e renale nel saturnismo. In Atti del XXI Congresso della Società Italiana di Medicina del Lavoro, p. 65. INAIL, Milan.

Crutcher, J. C. (1963). Clinical manifestations and therapy of acute lead intoxication due to the ingestion of illicitly distilled alcohol. Ann. intern. Med., 59, 707-715.

Dreessen, W. C., Edwards, T. J., Reinhart, W. H., Page, R. T., Webster, S. H., Armstrong, D. W., and Sayers, R. R. (194I). The control of the lead hazard in the storage battery industry. U.S. Publ. Hlth Bull. No. 262. Government Printing Office, Washington, D.C.

Emmerson, B. T. (1963). Chronic lead nephropathy and gout in Queensland. II International Congress of Nephrology, Prague. Excerpta Medica, International Congress Series, No. 67, p. 46.

Fishberg, A. M. (1939). Hypertension and Nephritis. p. 609. Baillière, Tindall and Cox, London.

Hamilton, A., and Hardy, H. (1949). Industrial Toxicology. p. 7I. Hoeber, New York.

Heilmeyer, L., and Krebs, H. A. (1930). Bestimmung der Harnsäure im Blutserum. Biochem. Z., 233, 365-372.

Henderson, D. A. (1955). Chronic nephritis in Queensland. Aust. Ann. Med., 4, 163-177.

- , and Inglis, J. A. (1957). The lead content of bone in chronic Bright's disease. Ibid., 6, 145-154.

Landing, B. H., and Hakai, H. (1959). Histochemical properties of renal lead inclusions and their demonstration in urinary sediment. Amer. F. clin. Path., 31, 499-503.
Lane, R. E. (1949). The care of the lead worker. Brit. $\mathcal{F}$. industr. Med., 6, 125-143.

Legge, T. M., and Goadby, K. W. (1912). Lead Poisoning and Lead Absorption. Edward Arnold, London; Longmans, Green, New York.

Nye, L. J. J. (1933). Chronic Nephritis and Lead Poisoning. Angus and Robertson, Sydney.

Oliver, T. (1914). Lead Poisoning. p. 98. Lewis, London.

Peters, J. (1956). The determination of creatinine and creatine in blood and urine. In Peters, J., and Van Slyke, D. D. Quantitative Clinical Chemistry. 2nd ed., pp. 598-604. Williams and Wilkins, Baltimore.

Pilat, L., Preda, N., and Muica, N. (1964). Diagnosticul saturnismului. Med. interna (Buc.), 16, 1 I01-1 108.

Preda, N., Lilis, Ruth, Nestorescu, B., and Roventa, Ana (1963). La valeur diagnostique du test de la plomburie provoquée à l'EDTA-Ca-Na ${ }_{2}$. XIV Congr. Intern. de Méd. du Travail, Madrid.

Radoševič, Z., Šarič, M., Beritič, T., and Kneźevič, J. (I96I). The kidney in lead poisoning. Brit. $\mathcal{F}$. industr. Med., 18, 222-230.

Rădulescu, I. C., Dinischiotu, G. T., Maugsch, C., Ionescu, C., and Teodorescu Exarcu, C. (1957). Recherches sur l'atteinte du rein dans le saturnisme industriel par l'étude de la clearance de la créatinine et de l'urée. Arch. Mal. prof., 18, 125-136.

Richet, C., Albahary, C., Ardaillou, R., Sultan, C., and Morel-Maroger, L. (1964). Le rein du saturnisme chronique. Rev. franç. Clin. Biol., 9, 188-196.

Vigdorcik, N. A. (1935). Lead intoxication in the etiology of hypertonia. F. industr. Hyg., 17, I-18.

Vigliani, E. (1950). Recenti studi sul saturnismo in Italia. Med. d. Lavoro, 41, I05-112.

Volhard, F., and Suter, F. (1918). Nieren u.Abl.Harnwege. In Handbuch der inneren Medizin. vol. 3, p. I532. Springer, Berlin.

With, T. K. (1955). Porphyrine concentration from ultraviolet extinction. Scand. F. clin. Lab. Invest., 7, 193-198. 